\title{
Influence of wood moisture content on bending and shear stiffness of cross laminated timber panels
}

\author{
Arne Gülzow • Klaus Richter • René Steiger
}

Received: 2 June 2009 / Published online: 9 February 2010

(C) Springer-Verlag 2010

\begin{abstract}
The bending and shear stiffness of cross-laminated timber (CLT) made from softwood depend on the moisture content of the panel. In principle, the stiffness properties drop with increasing moisture content within the hygroscopic range. However, swelling provokes closing of open gaps of the middle layers and leads to an apparent increase of stiffness due to internal friction. This increase in stiffness is only relevant for low deflections and can provoke misinterpretation of measuring results when deriving stiffness properties of CLT by means of dynamic methods such as modal analysis. Drying, on the other hand causes cracking within CLT, which manifests itself in a distinct reduction of the bending stiffness perpendicular to the grain direction of the face layers. Calculating bending stiffness of CLT perpendicular to the grain direction of the face layers by means of the compound theory not taking into account the face layers therefore is a common and correct procedure.
\end{abstract}

\section{Einfluss der Holzfeuchte auf die Biege- und Schubsteifigkeit von Brettsperrholzplatten}

Zusammenfassung Die Biege- und die Schubsteifigkeit von Brettsperrholz (CLT) aus Nadelholz sind von der Holzfeuchte der Platten abhängig. Die Steifigkeiten nehmen grundsätzlich mit zunehmender Holzfeuchte ab. Die Quellung der Brettlagen kann jedoch, einhergehend mit der

\footnotetext{
A. Gülzow

Carbo-Link GmbH, Undermülistrasse 26, 8320 Fehraltorf, Switzerland

K. Richter $\cdot$ R. Steiger $(\bowtie)$

Empa, Swiss Federal Laboratories for Materials Testing and Research, Wood Laboratory, Ueberlandstrasse 129, 8600 Dübendorf, Switzerland

e-mail: rene.steiger@empa.ch
}

Schließung offener Fugen, die Steifigkeit durch innere Reibung scheinbar erhöhen. Diese Steifigkeitserhöhung ist allerdings nur bei geringem Lastniveau relevant, was zu Fehlinterpretation bei Steifigkeitsmessungen mittels dynamischer Verfahren, wie z.B. der Modalanalyse führen kann. Das Austrocknen von Brettsperrholzplatten andererseits bewirkt Risse in den Brettlagen, was sich v. a. in einer markanten Reduktion der Steifigkeit senkrecht zur Faserrichtung der Decklagen äußert. Daher sollen die Decklagen bei der rechnerischen Ermittlung der Biegesteifigkeiten nach der Verbundtheorie als nicht mitwirkend betrachtet werden.

\section{Introduction}

Cross-laminated timber (CLT) is a panel-shaped engineered wood product which is assembled of layers of lamellas with perpendicular orientation of the grain direction. Compared to the raw material CLT plates exhibit homogenized mechanical properties. CLT is increasingly used for load bearing plates (floor elements) and panels (wall elements) in residential buildings and as deck plates in bridge constructions (Pohlmann and Mohr 1999; Schickhofer 1999, 2002; Schickhofer and Bernasconi 2002; Gülzow et al. 2007).

Within the hygroscopic range the mechanical properties of timber are subjected to changes depending on the moisture content (MC) of wood. The modulus of elasticity (MOE) in grain direction of defect free timber drops by approximately $1.5 \%$ if the wood moisture is increased by $1 \%$ (Hoffmeyer 1995). According to Kufner (1978) the variations of MOE as a function of the MC for different wood species are similar. Following the European standard EN 384 (CEN 2004), MOE determined on test specimens must be adjusted if the actual $\mathrm{MC}$ is not complying with a reference $\mathrm{MC}$ of $12 \%$ : in the MC range of 10 to $18 \%$, MOE can 


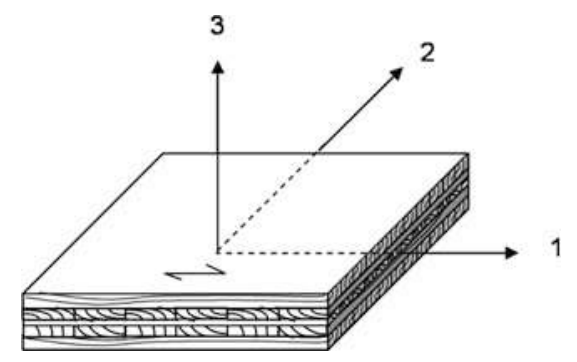

Fig. 1 Principal axes in CLT as used in this paper

Abb. 1 Definition der Hauptachsenrichtungen bei Brettsperrholz

be adjusted by $2 \%$ for every percentage point of difference in MC, in such way that the MOE increases if the data are adjusted from a higher MC to a lower one, and vice versa.

Being valid for single lamellas, the validity of the mentioned relation between $\mathrm{MC}$ and stiffness properties has to be studied for the cross-laminated compound material under different climate conditions. The changes in the most important stiffness parameters of CLT being the MOE parallel to the grain direction of the deck-layers $\left(E_{11}\right)$ and perpendicular to the grain of the deck-layers $\left(E_{22}\right)$ as well as the shear modules $\left(G_{12}, G_{23}, G_{13}\right)$ are analyzed in the following for changing MC (definition of the principle axes 1, 2, 3 of CLT: see Fig. 1). Furthermore it is examined if cracking of the deck-layers while drying the panels (Niemz and Wang 2002; Niemz et al. 2005) results in a reduction of MOE perpendicular to the grain direction of the deck-layers $\left(E_{22}\right)$.

\section{Material and method}

Investigations were carried out with an industrially produced CLT panel with a symmetric layer composition $(15 \mathrm{~mm} / 50 \mathrm{~mm} / 15 \mathrm{~mm})$ and dimensions of $3.7 \times 2.2 \mathrm{~m}^{2}$. Tangentially sawn boards of Norway spruce (Picea abies Karst.) with a thickness of $25 \mathrm{~mm}$ were used as raw material. The MC of the boards was $8 \%$; their strength class corresponded to C24 according to EN 338 (CEN 2003). Before assembling of the CLT, planking are produced by edge bonding of the single $25 \mathrm{~mm}$ lamellas. Making sure that there is a sufficient overlap of the single planking elements, several planking are bonded glulam-like at $130^{\circ} \mathrm{C}$ resulting in so-called "Blockholz" which is then vertically cut into layers being the raw material for the CLT production. All bonds are made with a melamine urea formaldehyde resin (MUF). Due to the high temperature used to accelerate the curing process, small cracks in all layers appear directly after production. It is not a common way of producing CLT from "Blockholz". Normally single boards are used resulting in gaps between the lamellas and in consequence less homogeneous product properties.

The CLT panel was stored in a climatized chamber for 12 months at reference conditions (climate $1: 20^{\circ} \mathrm{C}, 65 \% \mathrm{RH}$ ).
After reaching equilibrium MC 1 the geometrical dimensions as well as the weight of the panel were measured, and the stiffness parameters were determined applying a procedure which was developed by Gsell et al. (2007) and Gülzow et al. (2008): Resonance frequencies and mode-shapes of the hanging plate were determined by means of an experimental modal analysis. A simulation model based on a higher order plate theory was then used to estimate resonance frequencies and mode shapes. Finally, in an optimization process the unknown stiffness parameters were identified by minimizing the differences between measured and estimated resonance frequencies. As it was shown by verification on base of static bending tests (Gülzow et al. 2008), the method is capable of deriving stiffness properties of CLT with high accuracy.

Afterwards, the panel was divided into six equally sized specimens $\left(1.20 \times 1.10 \mathrm{~m}^{2}\right)$. The grain direction of the deck layers was parallel to the longer sides of the specimens. The weight and the geometrical dimensions of all specimens were measured again. The MC was determined in the center and in the corners of the panel, in depths of $1 \mathrm{~cm}$ and $3 \mathrm{~cm}$ using an electrical resistance meter (MC $1=12.0 \%$ \pm a variation in single measurements of $1.0 \%$ ). After determining the stiffness parameters of the specimens by modal analysis the test panels were again stored in a climatized chamber at the following conditions and storage times (climate $2: 20^{\circ} \mathrm{C}, 85 \% \mathrm{RH}, 8$ months; climate $3: 20^{\circ} \mathrm{C}, 35 \%$ RH, 4 months). MC 2 and 3 of the panels were measured for climate conditions 2 and 3, respectively. MC 2 was $18.5 \pm 1.4 \%$ and MC 3 was $10.6 \pm 1.4 \%$.

\section{Results and discussion}

For all six specimens the MOE parallel $\left(E_{11}\right)$ and perpendicular $\left(E_{22}\right)$ to the grain of the deck layers as well as the shear modulus $G_{12}$ in plane and the shear modules $G_{23}$ and $G_{13}$ could be determined by means of theoretical and experimental modal analysis. Due to the small sample size the significance of measured differences in stiffness properties as a result of changing moisture content could statistically not be proven. However, general tendencies regarding the mean values can be detected (Figs. 2 and 3 ) and allow drawing respective conclusions.

At increased MC 2, similar to solid timber the mean value of $E_{11}$ was lower compared to reference climate 1, whereas the mean value of $E_{22}$ did not change.

After drying to lower MC 3 of approximately 10\%, the MOE $E_{11}$ of most panels increased again and at the mean level reached the initial values of $E_{11}$ again.

The MOE $E_{22}$ dropped with increasing moisture. This was to be expected since the deck layers of the panels in standard climate did not show any cracks and all boards were bonded laterally. Thus, there was no increase in stiffness due to swelling. Furthermore, swelling in the middle 
Fig. 2 Graph of results: Mean MOE (dotted lines indicate reference value at initial $\mathrm{MC}$ of $12 \%)$

Abb. 2 Grafik der

Versuchsresultate: Mittlere

Elastizitätsmoduln (Die gestrichelte Linie repräsentiert den Referenzwert beim Startwert der Holzfeuchte von $12 \%$ )

Fig. 3 Graph of results: Mean shear modules (dotted lines indicate reference value at initial MC of $12 \%$ )

Abb. 3 Grafik der

Versuchsresultate: Mittlere

Schubmoduln (Die gestrichelte

Linie repräsentiert den

Referenzwert beim Startwert der

Holzfeuchte von 12\%)

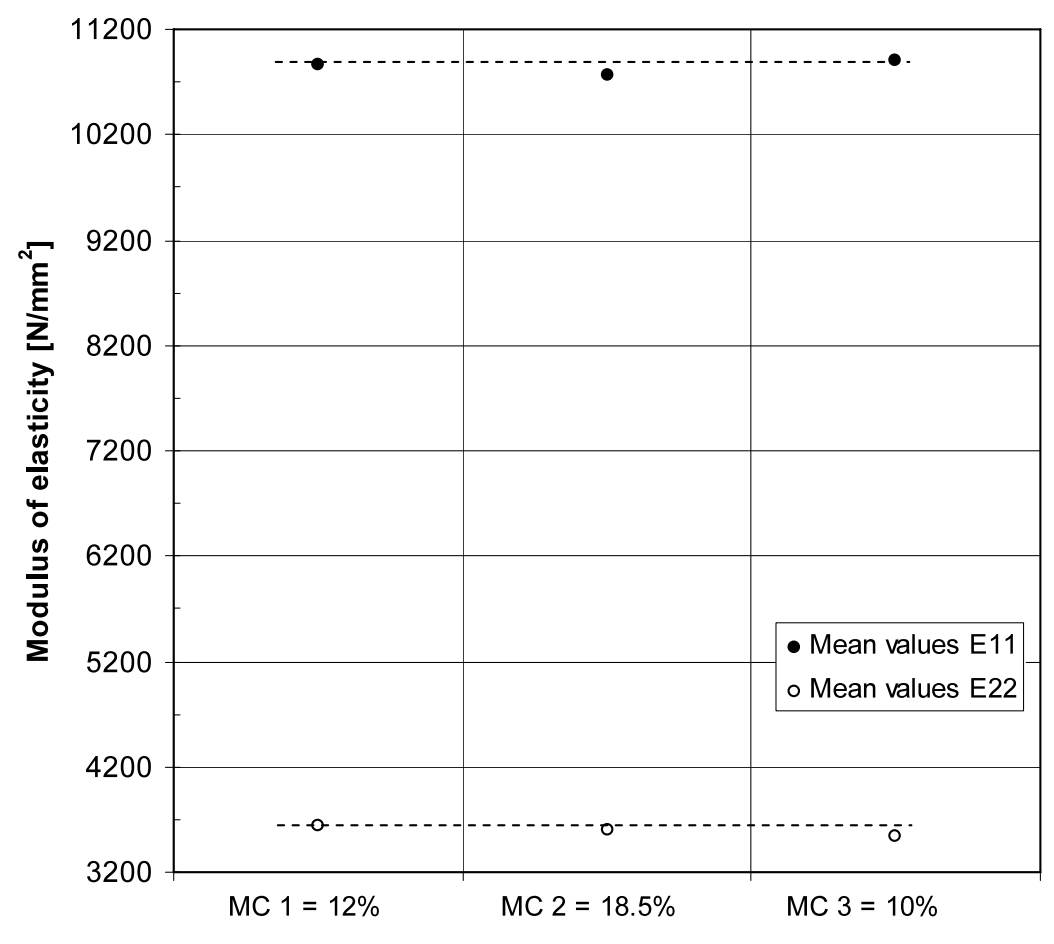

Moisture content

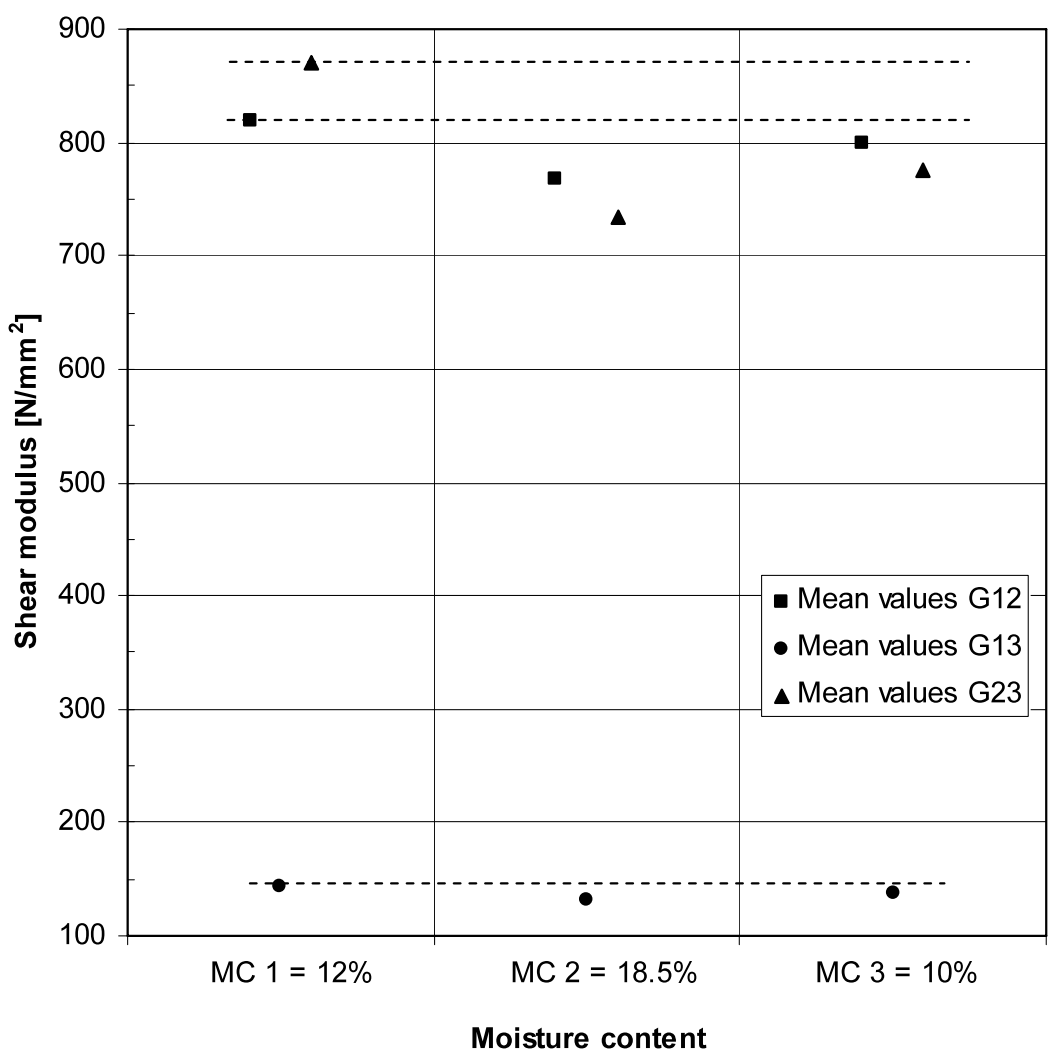

Moisture content lamellas does not influence the MOE $E_{22}$ since possible cracks would have formed along the grain, i.e., in direction 2 (Fig. 1). After drying the specimens to a MC of $10 \%, E_{22}$ is decreasing further. In accordance with reports from practice this can be explained by occurring cracks in the deck layers of the CLT panels (Fig. 4). Hence, when calculating 
Fig. 4 Cracks in the face layers after drying the CLT specimens to a MC of $10 \%$

Abb. 4 Rissbildung in den Decklagen nach Trocknung der Prüfkörper auf eine Holzfeuchte von $10 \%$

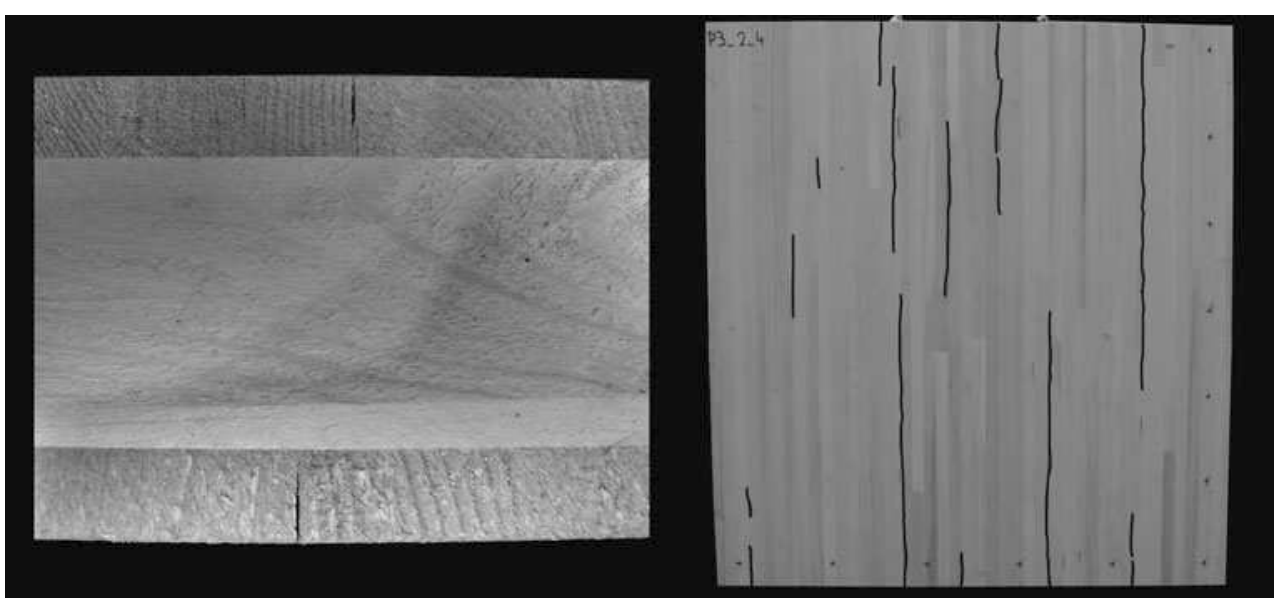

bending stiffness of CLT perpendicular to the grain direction of the face layers by means of the compound theory (Bodig and Jayne 1993; Blass and Görlacher 2003) taking the face layers not into account is a common procedure in the verification process (Jöbstl 2007a, 2007b).

The shear modules as well are responsive to changing wood moisture, crack formation and swelling (Fig. 3). They are dropping with increasing moisture and increasing when moisture is reduced. Due to the formation of cracks in all layers the initial values cannot be reached anymore after drying.

Opening and closing cracks of the layers due to shrinking and swelling affect the stiffness properties of CLT. The accuracy in determining the stiffness parameters of CLT by means of vibrations at different levels of moisture contents therefore is limited. Using vibration analysis and modal methods, only very small deflections of approximately $0.2 \mathrm{~mm}$ can be measured. At low stress levels internal friction in cracks and grooves remains active, which results in an apparently increased stiffness. This increase in stiffness therefore is only relevant for low deflections and can thus provoke misinterpretation of measuring results when deriving stiffness properties of CLT by means of dynamic methods such as modal analysis (Blumer et al. 2007).

\section{Conclusion}

Based on a small test series which aimed at studying the impact of changes of the wood moisture content (MC) on the stiffness parameters of cross-laminated timber panels (CLT), the following conclusions can be drawn:

- When increasing the $\mathrm{MC}$ from reference climate $\left(20^{\circ} \mathrm{C}\right.$, $65 \% \mathrm{RH}$ )) by storing the specimens in climate $20^{\circ} \mathrm{C} / 85 \%$ RH during 8 months, all investigated stiffness parameters $\left(E_{11}, E_{22}, G_{12}, G_{23}, G_{13}\right)$ decreased at their mean level.

- As a result of swelling the cracks in the middle lamellas of the CLT panels are closing. Due to increased lateral friction between the single boards this can result in apparently higher stiffness parameters of the CLT. This fact has to be taken into account when deriving stiffness parameters of CLT by means of dynamic methods, like e.g., modal analysis, since friction remains active only at low stress levels.

- Drying can cause cracks in all layers of CLT, which, as a result can lead to a reduction of the MOE perpendicular to the grain of the deck layers $\left(E_{22}\right)$. Since drying-cracks can always occur in practice, neglecting the stiffnesscontingents of the deck layers when calculating $E_{22}$ on base of the compound theory is a common and correct procedure.

Acknowledgements The study was financially supported by the Swiss Federal Office for the Environment FOEN (Fonds zur Förderung der Wald- und Holzforschung). The test specimens were supplied by Pius Schuler AG, CH-6418 Rothenthurm, Switzerland (www.piusschuler.ch). The assistance of the Empa technician B. Maag taking care of preparation of specimens is gratefully acknowledged.

\section{References}

Blass HJ, Görlacher R (2003) Bemessung im Holzbau: Brettsperrholz - Berechnungsgrundlagen. In: Holzbau-Kalender. Bruder-Verlag, Karlsruhe, pp 580-598

Blumer S, Howald M, Niemz P (2007) Ermittlung ausgewählter mechanischer Eigenschaften von Massivholzplatten mittels Eigenfrequenz, Teil 2: Versuchsergebnisse und Interpretation. Holztechnologie 48(3):27-32

Bodig J, Jayne BA (1993) Mechanics of wood and wood composites. Krieger, Malabar

CEN (2003) EN 338: Structural timber-strength classes. European Committee for Standardization, Brussels

CEN (2004) EN 384: Structural timber-determination of characteristic values of mechanical properties and density. European Committee for Standardization, Brussels

Gsell D, Feltrin G, Schubert S, Steiger R, Motavalli M (2007) Cross laminated timber plates: evaluation and verification of homogenized elastic properties. Journal of Structural Engineering 133(1):132-138 
Gülzow A, Steiger R, Gsell D Wilson W, Feltrin G (2007) Dynamic field performance of a wooden trough bridge. In: Proceedings of EVACES'07: experimental vibration analysis for civil engineering structures, Porto, Portugal, pp 181-182

Gülzow A, Gsell D, Steiger R (2008) Zerstörungsfreie Bestimmung elastischer Eigenschaften quadratischer 3-schichtiger Brettsperrholzplatten mit symmetrischem Aufbau. Holz Roh- Werkst 66(1):19-37

Hoffmeyer P (1995) Holz als Baustoff. In: Holzbauwerke nach dem Eurocode 5, Step 1: Bemessung und Baustoffe. Fachverlag Holz der Arbeitsgemeinschaft Holz e.V., Düsseldorf, pp A4/1-A4/22

Jöbstl RA (2007a) Praxisgerechte Bemessung von Brettsperrholz. In: Tagungsband Ingenieurholzbau; Karlsruher Tage 2007. Bruderverlag, Karlsruhe, pp 50-61

Jöbstl RA (2007b) Traglastnachweis für Brettsperrholz auf Basis der starren Verbundtheorie unter Berücksichtigung von Systemeffekten. In: Tagungsband zum 39. SAH-Fortbildungskurs. 7./8. November 2007, Weinfelden, Schweiz, pp 9-23.

Kufner M (1978) Elastizitätsmodul und Zugfestigkeit von Holz verschiedener Rohdichte in Abhängigkeit vom Feuchtigkeitsgehalt. Holz Roh- Werkst 36(11):435-439
Niemz P, Wang X (2002) Spannungsausbildung in dreischichtigen Massivholzplatten bei Klimawechsel. Holzforsch Holzverwert 54(4):82-83

Niemz P, Bärtschi H, Howald M (2005) Investigation of moisture distribution and stress formation in timber construction materials under changing climatic conditions. Schweiz Z Forstwes 156(34):92-99

Pohlmann J, Mohr B (1999) Innovativer Plattenbalkenquerschnitt. Bauen Mit Holz 101(12):14-19

Schickhofer G (1999) Strassenbrücken aus Holz - Ausgeführte Beispiele. In: Brücken aus Holz. Fachverlag Holz der Arbeitsgemeinschaft Holz e.V., Düsseldorf, pp 79-93

Schickhofer G (2002) Brettsperrholz: Anwendungen und Konstruktionsdetails im mehrgeschossigen Wohn- und Kommunalbau. In: Tagungsband Ingenieurholzbau - Karlsruher Tage 2002. Bruderverlag, Karlsruhe, pp 284-305

Schickhofer G, Bernasconi A (2002) Holzbaukonstruktionen - Der moderne Holzbrückenbau: Tragstrukturen und Fahrbahnkonstruktionen. In: Holzbau-Kalender. Bruder-Verlag, Karlsruhe, pp 704-739 